\title{
Chromosome 2
}

\section{Figure A}

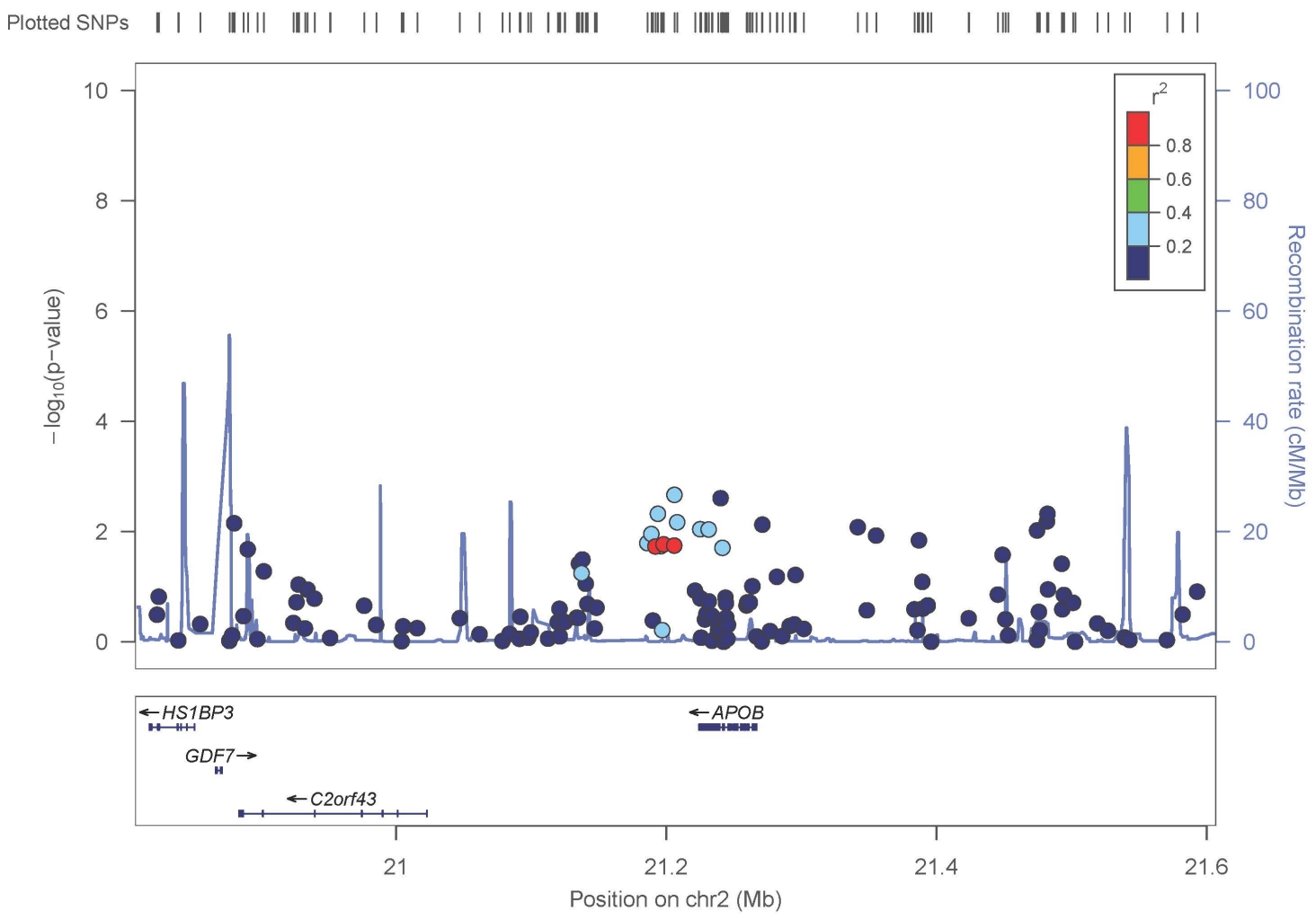

Chromosome 2

Figure B

Chr 2

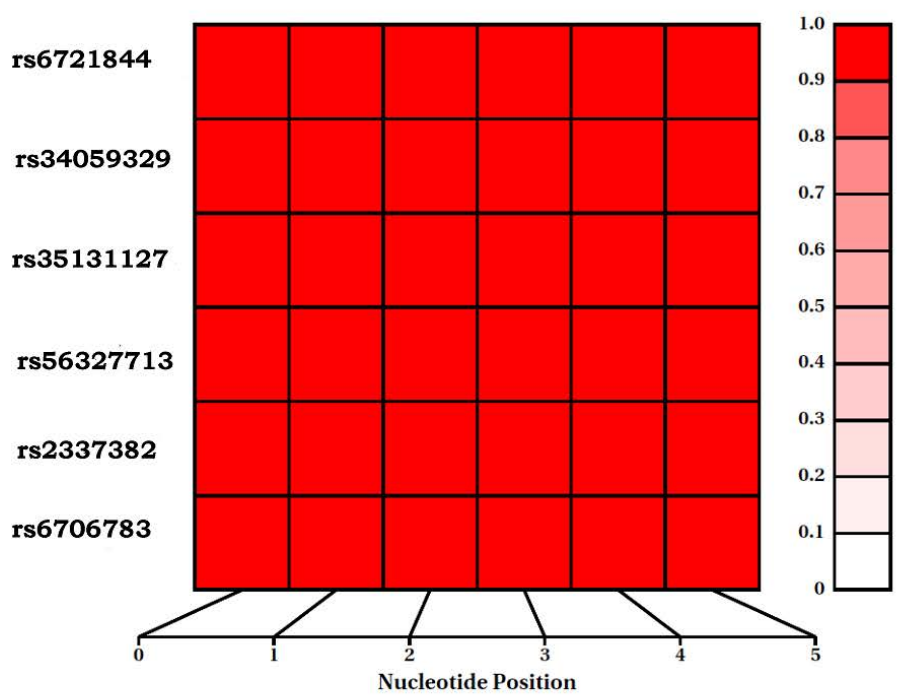

